\title{
Bacterial Needle Blight of Chinese Fir (Cunninghamia lanceolate Hook) Caused by Pseudomonas syringae pv. cunninghamiae pv. nov.*
}

\author{
Xue-You HE** and Masao GoTo***
}

Key words : new bacterial disease, forest disease, bacterial taxonomy.

Chinese fir (Cunninghamia lanceolate Hook) is widely planted for timber in the southern part of China. Bacterial needle blight of this plant was first reported in 1977 in the anonymity from Nanjing Forest Products Industrial College (Nanjing), Forest Pest Control Experimental Station of Jiangxi (Yiyang), and Beling Forestry Station, Jinxian County, Jiangxi (Jinxian) ${ }^{7}$. The disease was characterized by brown, small and water-soaked spots with translucent margins which gradually killed the needles. The pathogen was named Pseudomonas cunninghamiae. However, this name was neither adopted in Approved Lists of Bacterial Names ${ }^{9)}$ nor approved as a valid name subsequently ${ }^{6}$, because the cultures were not available from type culture collections ${ }^{3)}$. In addition, the name was inadequately published because the authors were not individuals but research organizations ${ }^{3)}$. The name $P$. cunninghamiae, therefore, has no standing in bacterial nomenclature in these days.

In 1992, we found occurrence of a similar disease of Chinese fir in southern part of Fujian Province, China. The disease appeared at first as yellow to yellowish brown, water-soaked dots with yellow haloes on needles and stems of young shoots. These dots gradually enlarged to form light brown to brown, water-soaked, round to elliptical spots 2 to $6 \mathrm{~mm}$ in longitudinal diameter with yellow haloes. The spots on mature leaves were often reddish brown to dark brown and showed greasy appearance with no visible haloes. The margin of the lesion was usually indistinct on the underside of the needles. The lesions often coalesced each other forming large blotches which covered a half to whole area of a needle. When infection occurred severely, whole twigs died in gray to grayish brown (Fig. 1). These symptoms were identical with those of bacterial needle blight described in China in 1977.

We isolated 6 strains (PC1 to $\mathrm{PC} 6$ ) of the causal bacterium from the diseased plant samples collected at Dayuan, Jiangle County and Jiefu, Yongchun County, Fujian Province. All strains satisfied Koch's postulates in the inoculation tests on Chinese fir. In artificial inocu- lation through wounds and stomata, the bacterium produced on the needles of $C$. lanceolate small, yellow and water-soaked dots a week after inoculation. These dots gradually enlarged to form the typical lesions identical to those by natural infection in several weeks (Fig. 1). In the inoculation tests, the bacterium also produced similar symptoms on the leaves of Agathis heterophylla, Cryptomeria fortunei, Podocarpus nagi and Taxodium ascendens. In contrast, pathogenicity to the following plants was all negative: Actinidia chinensis, Allamamda neriifolia, Boehmeria nivea, Bougainvillea spectabilis, Brassica olerasea var. capitata, Capsicum annum var. frutescens, Chukrasia tabularis, Cinnamomum camphora, C. cassia, Citrus limon, C. sinensis, Colocasia esculenta, Cucumis sativus, Dicranopteris dichotoma, Dimocarpus longan, Eriobotrya japonica, Eucalyptus citriodora, E. globulus, Ficus erecta, Iris sp., Litchi chinensis, Luffa cylindrica, Lycopersicon esculentum, Melastoma candidum, Metasequoia glyptostroboides, Michelia figo, Morus spp., Musa nana, Myrica rubra, Nerium indicum, Olea europaea, Phaseolus vulgaris, Podocarpus macrophylla, Prunus mume, P. persica, P. yedoensis, Rhus chinensis, Schima superba, Smilax china, Syringa vulgaris, Taxodium distichum, Woodwardia japonica and Zea mays. The bacterium was positive in tobacco hypersenstive reaction, but did not produce soft rot on potato slices and leaves of Chinese cabbage and cabbage.

The bacterium was identical to the group Ia in LOPAT test ${ }^{4)}$, and shared many cultural, physiological and biochemical properties ${ }^{2)}$ with Pseudomonas syringae pathovars $^{4,8}$. However, it was distinct from $P$. syringae pathovars in the host specificity and the ability to use $\beta$-alanine and 2-ketogluconate as a sole source of carbon. The pathogen of bacterial needle blight of Cunninghamia lanceolate is, therefore, regarded as a new pathovar of $P$. syringae, for which the name $P$. syringae pv. cunninghamiae is proposed. The strain PC1 is designated as the pathotype strain of the bacterium and was deposited in the American Type Culture Collection (ATCC51416) and International Collection of Micro-

* This study is a part of Fujian Forestry Technology Development Project research supported by Japan International Cooperative Agency.

** Research Department of Forest Protection, Fujian Research Institute of Forestry, Xin Dian, Fuzhou 350012, China 中国福建省林業科学研究所

*** Faculty of Agriculture, Shizuoka University, 836 Ohya, Shizuoka 422, Japan＼cjkstart静岡大学農学部 


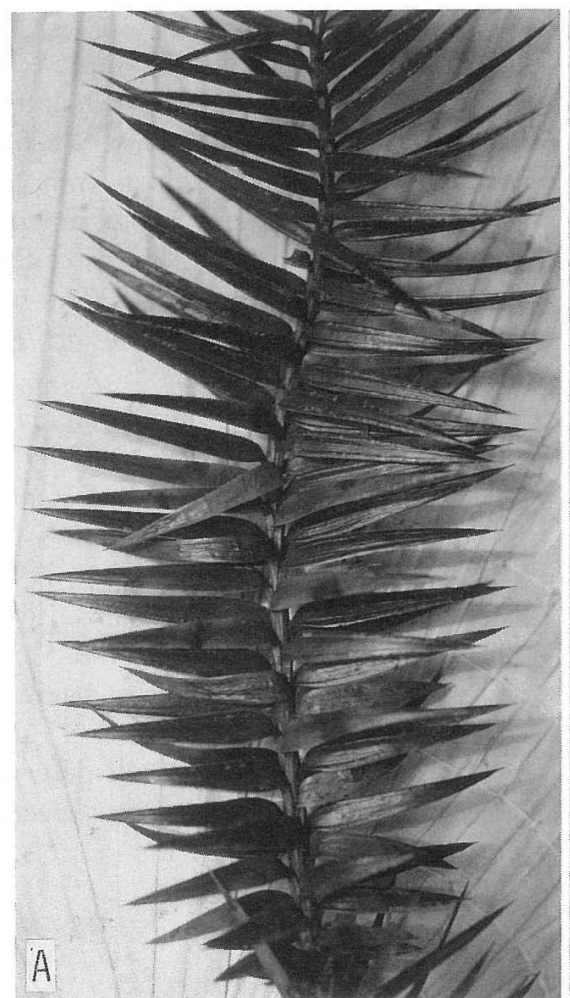

A

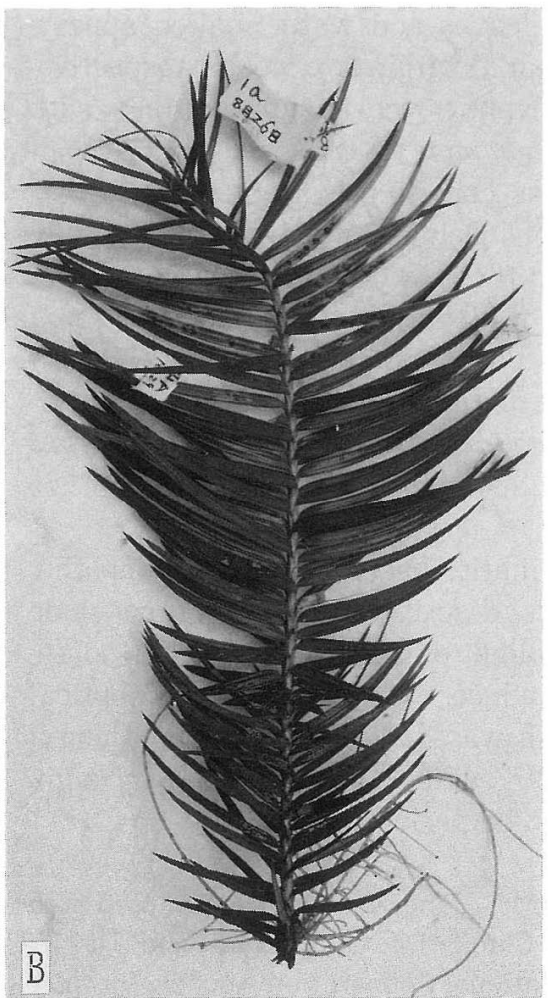

B

Fig. 1. Symptoms of bacterial needle blight of Chinese fir by natural infection (A) and artificial inoculation (B).

organisms from Plants (ICMP11894). The description of $P$. syringae pv. cunninghamiae is as follows.

Pseudomonas syringae pv. cunninghamiae pv. nov. All strains of this bacterium were Gramnegative, straight rods with round ends, $0.5-0.7 \times 1.9-3.0$ $\mu \mathrm{m}$ in size $(0.5 \times 2.6 \mu \mathrm{m}$ in average). The bacterium was motile by means of one to seven polar flagella. Colonies grown on yeast extract-peptone agar (YPA) plates for $48 \mathrm{hr}$ at $28^{\circ} \mathrm{C}$ were 0.5 to $1.6 \mathrm{~mm}$ in diameter, white, convex, translucent, glistening, circular with smooth surface and entire margin. Growth on YPA slant was moderate, white and butyrous at first but viscid later. All strains were positive in the following tests: production of fluorescent pigment on King's B medium, levan formation from sucrose, production of catalase, hydrolysis of pectin and Tween 80, utilization of asparagine as a sole source of carbon and nitrogen, production of ammonia, alkaline reaction in litmus milk, and use as a sole source of carbon of L-arabinose, D- $(+) x y l o s e, ~ D-(-)$ fructose, galactose, glucose, sucrose, inositol, Dmannitol, D-sorbitol, trans-aconitate, 2-ketogluconate, mucate, protocatechuate, $\mathrm{D}-(-)$-quinate, $\mathrm{L}-(+)$-tartrate, and $\beta$-alanine.

The following tests were negative for all-strains: accumulation of poly- $\beta$-hydroxybutyrate granules, production of acetoin, hydrogen sulfide, indole, 3-ketolactose and reducing substances from sucrose, nitrate reduction, denitrification, methyl red test, hydrolysis of carboxymethyl cellulose, casein, DNA, esculin, gelatin and starch, growth factor requirement, reactions for arginine dihydrolase, lecithinase, oxidase, phenylalanine deaminase, phosphatase, tyrosinase and urease, oxidation of gluconate, and use of D-arabinose, lactose, maltose, trehalose, D- $(+)$-melezitose, raffinose, dextrin, glycogen, poly-(3-hydroxybutyrate), salicin, adonitol, geraniol, meso-erythritol, propylene glycol, adipate, alginate, DL-2-amino- $n$-butyrate, anthranilate, azelate, benzoate, $n$-butyrate, citraconate, ferulate, hexanoate, $m$-hydroxybenzoate, 4-hydroxy-2-quinoline carboxylate, itaconate, levulate, malonate, $( \pm)$-mandelate, mesaconate, pimelate, sebacate, suberate, D-(-)-tartrate, $n$-valerate and L-valine.

Maximum $\mathrm{NaCl}$ tolerance was 4\%. Growth occurred at $\mathrm{pH}$ range between 4.0 and 9.5 with the best growth at pH 6.5 to 7.5. Maximum, minimum and optimum growth temperatures were 36,6 , and $28^{\circ} \mathrm{C}$, respectively. The $\mathrm{G}+\mathrm{C}$ content of the DNA determined by ultraviolet spectroscopy ${ }^{5,10)}$ was $66 \mathrm{~mol} \%$. The ubiquinone species analyzed by Collins method ${ }^{1)}$ was Q9. The bacterium causes leaf spot disease resulting finally in needle blight on Cunninghamia lanceolate by natural infection, and Agathis heteropylla, Cryptomeria fortunei, Podocarpus nagi and Taxodium ascendens by artificial inoculation.

The bacteriological properties of $P$. syringae pv. cunninghamiae pv. nov. mentioned above were analogous to those of $P$. cunninghamiae ${ }^{7)}$, although the description of the latter was substantially concise. The pathogenic traits of $P$. syringae pv. cunninghamiae and $P$. cunninghamiae were in agreement each other except for the pathogenicity on Phaseolus vulgaris. The pathogenic reaction of $P$. cunninghamiae on this plant was reported to be weak i.e., small necrotic spots produced around 
pricks dropped from leaves and water-soaked appearance on stems disappeared within two weeks, respectively. In the present study, however, inoculation tests with P. syringae pv. cunninghamiae on the leaves and pods of kidney bean plant was consistently negative. In other respects, the results of inoculation tests were generally in agreement between these two bacteria, although we could not confirm the pathogencity to Taiwania flousiana because this plant was not available. Alternatively, we proved the pathogenicity of $P$. syringae pv. cunninghamiae on Agathis heterophylla and Podocarpus nagi which was not listed in the host plants of $P$. cunninghamiae ${ }^{7}$.

From such symptomatic, bacteriological and pathological characteristics described above, we conclude that bacterial needle blight of Chinese fir found in southern part of Fujian Province, China in 1992 was identical with the disease which was first reported from Jiangxi Province, China in 1977 with P. cunninghamiae (nom. rej.) as the pathogenic bacterium.

We are indebted to Mr. Yang Zongwu, Fujian Research Institute of Forestry, China, Dr. S. Mikami and Dr. T. Matsuura, Japan International Cooperation Agency, for their consistent encouragements and support for this research.

\section{Literature cited}

1. Collins, M.D. (1985). Analysis of isoprenoid quinones. In Methods in Microbiology, Vol. 18 (Gottschalk, G. ed.), Academic Press, Inc., New York, pp. 329-366.

2. Cowan, S.T. (1974). Cowan and Steel's Manual for the Identification of Medical Bacteria, 2nd ed., Cambridge University Press, Cambridge.

3. Lapage, S.P., Sneath, P.H.A., Lessel, E.F., Skerman, V. B.D., Seelinger, H.P.R. and Clark, W.A. eds. (1975). International Code of Nomenclature of Bacteria. American Society for Microbiology, Washington, D.C.

4. Lelliott, R.A., Billing, E. and Hayward, A.C. (1966). A determinative scheme for the fluorescent plant pathogenic pseudomonads. J. Appl. Bacteriol. 29 : 470-489.

5. Marmur, J. (1961). A procedure for the isolation of deoxyribonucleic acid from microorganisms. J. Mol.
Biol. $3: 208-218$.

6. Moore, W.E.C. and Moore, L.V.H. (1992). Index of the Bacterial and Yeast Nomenclatural Changes, American Society for Microbiology, Washington, D.C.

7. Nanjing Forest Products Industrial College (Nanjing), Forest Pest Control Experimental Station of Jiangxi (Yiyang), and Beling Forestry Station, Jinxian County, Jiangxi (Jinxian) (1977). The bacterium which causes needle blight of Chinese fir: Pseudomonas cunninghamiae sp. nov. Acta Microbiologica Sinica 17 : 179-182 (in Chinese with English summary).

8. Palleroni, N.J. (1984). Family 1, Pseudomonadaceae Winslow, Broadhurst, Buchanan, Krumwiede, Rogers, and Smith 1917. In Bergey's Manual of Systematic Bacteriology, Vol. 1 (Krieg, N.R. and Holt, J.G. eds.), The Williams \& Wilkins, Baltimore, pp. 141-219.

9. Skerman, V.B.D., McGowan, V. and Sneath, P.H.A. eds. (1980). Approved lists of bacterial names. Int. J. Syst. Bacteriol. $30: 225-420$.

10. Ulitzer, S. (1972). Rapid determination of DNA base composition by ultraviolet spectroscopy. Biochim. Biophys. Acta $272: 1-11$.

\section{和 文 摘 要}

何 学友・後藤正夫：Pseudomonas syringae pv. cunninghamiae pv. nov. によるコウヨウザン (Cunninghamia lanceolate Hook）の葉枯細菌病について

中国で 1977 年に発表されたPseudomonas cunninghamiae によるコウヨウザン葉枯細菌病は, 病原細菌の学名が国際細菌 命名規約の改定によって失効したまま現在に至っている。筆者 等は 1992 年に福建省南部地方で発見されたコウヨウザンの細 菌病について, 病徵, 病原菌の細菌学的性質および寄生性の検討 を行った。その結果, 本病害は病徵および病原菌の性質から上記 の葉枯細菌病と同一の病害と認められた。本病原細菌はインゲ ンに寄生性を示さず, Agathis heterophylla および Podocarpus nagi に病原性を示す点でP. cunninghamiae の記載と異なっ た。細菌学的性質は炭素源として $\beta$-アラニンおよび 2 -ケトグ ルコン酸を利用する点を除いて P. syringae pathovarsのそれ に一致した。そこで本細菌を P. syringae pv. cunninghamiae pv. nov. と命名し，PC1 菌株（ATCC51416, ICMP11894）を基 準菌株に指定する。

(Received February 28, 1994) 